- response that causes diseases such as rheumatoid arthritis and lupus. The candidate drug's targets occur in only two species: humans - in whom safety tests of the compound would be ethically impermissible - and chimpanzees. If the study is killed, "this line of investigation will probably have to stop", says one observer with knowledge of the study.

Although the IOM committee was unanimous in declaring chimpanzees unnecessary for almost all invasive research, it was split on whether the animal is essential for developing a vaccine against hepatitis $C$, which kills some 350,000 people globally each year. The chimpanzee is the only animal model that can test whether an immune response to a candidate vaccine would protect against hepatitis $\mathrm{C}$ infection. One of the nine studies now in jeopardy explores why the immune response in chimpanzees often cannot clear hepatitis $\mathrm{C}$ infections.

"Everybody working with chimpanzees in the hepatitis $C$ field realizes that they are really unique animals," says Stanley Lemon, who studies hepatitis $\mathrm{C}$ at the University of North Carolina, Chapel Hill, and who resigned from the NIH working group last year. "But you have to balance that against the weight of human morbidity and mortality."

The working group also recommended that five of 13 behavioural and comparative-genomics studies should end. The Yerkes National Primate Research Center in Atlanta, Georgia, hosts some of these studies, which include an assessment of the roles of the hormones vasopressin and oxytocin in social cognition, and a look at how genes and early social experiences affect brain development and behaviour.

Even if Collins allows the Yerkes studies to continue, the recommendation for new housing requirements could doom the projects. The working group proposed the provision of 6.1 vertical metres of climbing structure and 93 square metres of space for each animal; fresh materials for daily construction of nests; foraging opportunities; and housing in social groups of at least seven. "We estimate it could cost tens of millions of dollars for our centre alone to renovate space that will have limited use given our ageing colony," says Yerkes spokeswoman Lisa Newbern.

Some ethicists say that if Collins embraces the recommendations, his decision will not only mark the end of most government-supported chimpanzee research, but also raise questions about work on other non-human primates. The NIH supports a network of primate research centres that houses some 27,000 non-human primates of 20 species. "We're not going to suddenly decide that all primates have got to be retired," says Gregory Kaebnick, a research scholar at the Hastings Center in Garrison, New York, who last month led a study on changing ethical views on animal research. "But we might find ourselves trying to reassess the way we've been using them." -

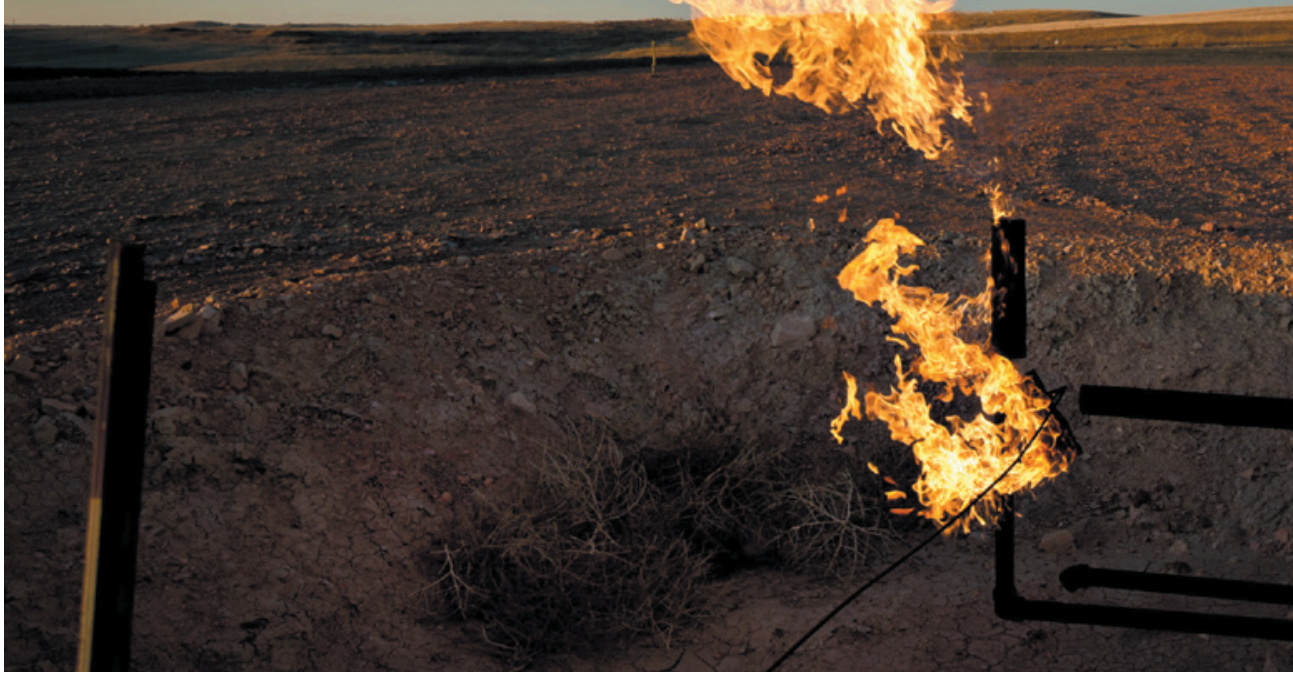

Natural gas from oil wells in North Dakota is often burned rather than captured and sold.

ENERGY

\title{
Oil boom raises burning issues
}

\section{Unburned methane could be adding to the environmental impact of gas flares in North Dakota.}

\section{BY JEFF TOLLEFSON}

W hen Paul Shepson flew his twinpropeller Beech aircraft over the Williston Basin in North Dakota last June, the perverse economics of a modern-day energy bonanza were on vivid display. Shepson, an atmospheric chemist at Purdue University in West Lafayette, Indiana, saw 10-metre-high flames writhing in the wind as shale-oil producers burned off the natural gas that was coming up along with the oil - a valuable resource that here, far from gas pipelines, is just a nuisance.

In 2011, North Dakota's oil producers flared around 1.4 billion cubic metres of natural gas, according to the Energy Information Administration (EIA) in Washington DC. That was nearly $32 \%$ of the total amount of gas produced by the state, and enough to heat around 700,000 houses. And the flaring increased in 2012. Scientists are just beginning to assess how the carbon dioxide from the flames adds to the climate footprint of the oil, and how black carbon and other pollutants affect local air quality.
But Shepson has also begun to detect evidence of a hidden threat: plumes of pure methane - a much more potent greenhouse gas than $\mathrm{CO}_{2}-$ that is either leaking from the oil and gas infrastructure or being vented by extractors who are not flaring. Although he has yet to quantify the methane emissions, Shepson says that the energy coming out of the basin could have a steeper environmental price than many realize.

Over the past several years, companies have been using the same hydrofracturing technologies that have spurred a broader US gas rush to drill thousands of oil wells into the Bakken shale formation, which stretches across North Dakota, Montana and the Canadian province of Saskatchewan. High oil prices are driving the boom, which some predict could help to make the United States the world's largest oil producer by 2020. Companies that build pipelines and gas-processing plants simply cannot keep up.

Some $65 \%$ of the oil from the Bakken shale is now being shipped out by rail. But the raw natural gas that bubbles up along with it - a mixture of lighter liquid hydrocarbons and 


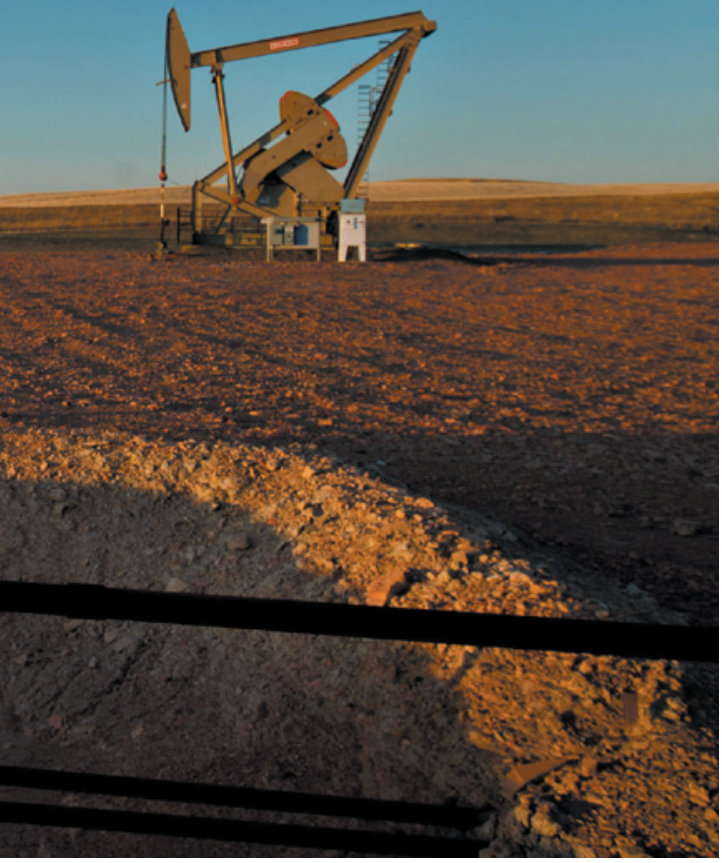

gases such as propane, butane and methanerequires both pipelines and processing, says Rusty Braziel of RBN Energy, a consultancy based in Houston, Texas. Some of the liquid gas is shipped to Canada, where it is used to dilute raw bitumen from the Alberta tar sands for shipment back to the United States, but production has so far outpaced demand. "The companies would love to sell that natural gas," says Rich Alonso, a partner at Bracewell \& Giuliani, an industry lobbying firm based in Washington DC. But "it has got no place to go".

\section{BURNING PROBLEM}

The upshot is flaring, and lots of it. North Dakota's flaring rose more than sixfold between 2006 and 2011, and total US flaring increased by $62 \%$ over the same period, according to the EIA. Satellite data from researchers at the National Oceanic and Atmospheric Administration in Boulder, Colorado, show that even before the shale-oil boom, the United States was flaring more gas than all but a handful of countries, including Russia, Nigeria, Iran and Iraq.

Environmentalists are pushing North Dakota to halt flaring and require that the gas be used to produce electricity or be processed into usable products, such as fertilizer. Scientists and entrepreneurs are working on mobile

\section{UP IN SMOKE}

The proportion of the natural gas being vented or flared during shale-oil operations in North Dakota hovers at around one-third, but carbon dioxide emissions have grown with booming production.

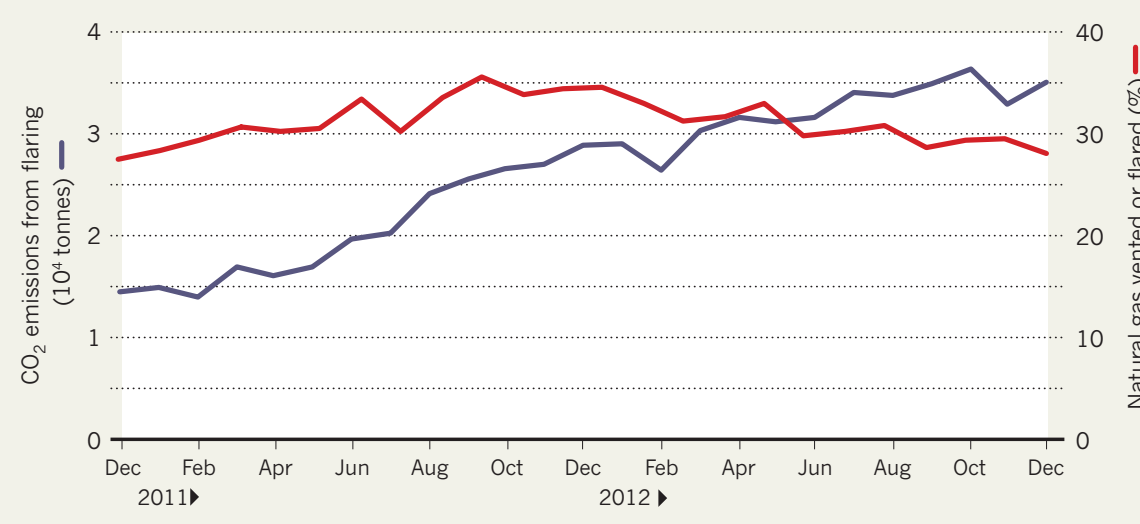

refineries that could be deployed in the field to process the stranded gas. And at the federal level, environmentalists are asking the US Environmental Protection Agency to regulate methane emissions under the Clean Air Act. But there is no obvious resolution in sight.

"It's being treated as an infrastructure problem, but I see it first and foremost as a regulatory problem," says Brad Crabtree, policy director for the Great Plains Institute, an environmental advocacy organization based in Minneapolis, Minnesota. "The industry can afford to manage the gas and should be required to do so." Industry officials say that gas infrastructure is already expanding and argue that regulations would only slow that development.

Shepson initially focused his investigations on the flares, hoping to measure the pollutants they emit and how much methane was escaping unburned. He and his crew flew through the plumes rising from 11 major flares, and found that they were highly efficient, burning all but around $0.1 \%$ of the methane. But the team also documented numerous plumes of pure methane, suggesting that natural gas is escaping directly into the atmosphere in many locations. This is particularly troubling because, molecule for molecule, methane has roughly 25 times the warming power of $\mathrm{CO}_{2}$.

Exactly how much methane is escaping remains unclear, however, as does its source, although some suspect that flaring is not as universal a practice as believed. "We don't have an estimate for how leaky the Bakken is in terms of methane emissions, but if you are going to flare the gas anyway you probably aren't going to be too careful," says David McCabe, an atmospheric scientist at the Clean Air Task Force, an environmental group based in Boston, Massachusetts, which funded the work.

Scientists are just beginning to incorporate this information into life-cycle greenhouse-gas assessments of shale-oil developments. The oil coming out of the Bakken formation is highquality light crude, which produces fewer $\mathrm{CO}_{2}$ emissions than thick oil from the Canadian tar sands or Venezuela. But no one knows for sure how natural-gas leakage and flaring affect that "If you are going equation. Assuming a best-case scenario in to flare the gas anyway, you probably aren't going to be too careful." which all the methane is combusted, McCabe estimates that the flares would have generated nearly 4 million tonnes in $\mathrm{CO}_{2}$ emissions over the course of 2012 (see ' $\mathrm{Up}$ in smoke'), akin to running a medium-sized coal-fired power plant in the prairie. The leaking methane could add substantially to that climate impact.

Shepson says he hopes to get a clearer reading of the methane leakage during a second round of investigations this year, but he is worried about the big picture. "When you fly over this region, what hits you is the scale of the development," he says. "We are reinvesting in an aggressive way in fossil fuels, and the price of all of that will be a more certain and larger impact from climate change." - SEE EDITORIALP.281

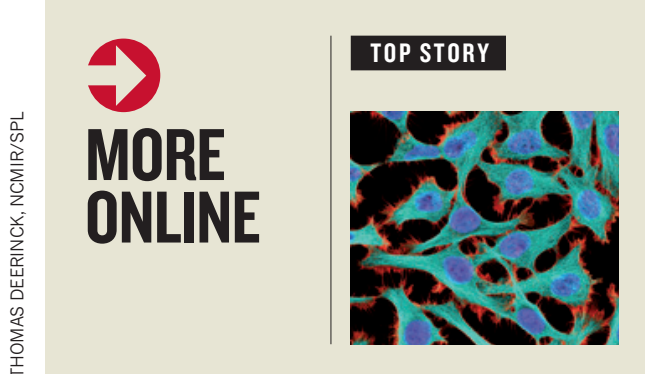

Sequencing finds HeLa cell genome riddled with errors go.nature.com/ inxzuw

\section{MORE NEWS}

- Super-dense extrasolar objects could be new type of planet go.nature. com/3ttifq

- Early birds flew on four wings go.nature.com/6zem1p

- Obama unveils US\$2-billion plan to get US cars off petrol go.nature.com/zdzpyd

\section{VIDEO}

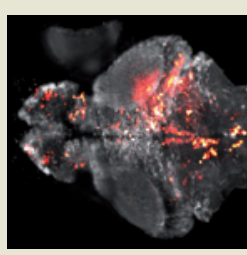

Whole-brain imaging shows fish's activity down to single neurons go.nature.com/ viqdja 